This item was submitted to Loughborough's Research Repository by the author.

Items in Figshare are protected by copyright, with all rights reserved, unless otherwise indicated.

\title{
Spatial and social transformations in a secondary city: the role of mobility in Sekondi-Takoradi, Ghana
}

PLEASE CITE THE PUBLISHED VERSION

http://dx.doi.org/10.1080/00167223.2017.1343672

\section{PUBLISHER}

Taylor \& Francis (c) The Royal Danish Geographical Society

\section{VERSION}

AM (Accepted Manuscript)

\section{PUBLISHER STATEMENT}

This work is made available according to the conditions of the Creative Commons Attribution-NonCommercialNoDerivatives 4.0 International (CC BY-NC-ND 4.0) licence. Full details of this licence are available at: https://creativecommons.org/licenses/by-nc-nd/4.0/

\section{LICENCE}

CC BY-NC-ND 4.0

\section{REPOSITORY RECORD}

Yankson, Paul W.K., Katherine Gough, James Esson, and Ebenezer F. Amankwaa. 2019. "Spatial and Social Transformations in a Secondary City: The Role of Mobility in Sekondi-takoradi, Ghana". figshare. https://hdl.handle.net/2134/25588. 


\title{
Spatial and social transformations in a secondary city: the role of mobility in Sekondi-Takoradi, Ghana
}

\begin{abstract}
:
Existing research on urban Ghana mainly focuses on processes occurring within the country's major cities, thereby reproducing a trend within the social sciences to overlook the role of intermediate and secondary cities. This paper aims to address this shortcoming by exploring spatial and social transformations in Sekondi-Takoradi, one of Ghana's secondary cities and the metropolitan area serving the region's emerging rubber industries as well as the country's oil and gas economy. Using qualitative interviews conducted with residents in five of the city's neighbourhoods, and a modified version of Kaufmann's typology of mobility, we examine migration into Sekondi-Takoradi, residential mobility within the city, and the daily mobility of the city's residents. The paper highlights how these diverse forms of mobility interact with processes taking place both within and outside Sekondi-Takoradi, most notably influencing and being influenced by livelihood strategies. It is argued that the city and its hinterlands can best be envisaged as a mobile networked whole, rather than consisting of disconnected and compartmentalised locales. The paper thus contributes to broader debates on how mobility shapes urbanisation by providing new empirical data on events unfolding in Africa's secondary cities, and extends existing research by providing a counter narrative to literature that examines the city and its surrounding rural areas separately.
\end{abstract}

Keywords: mobility, urban, secondary cities, qualitative methods, Sekondi-Takoradi, Ghana 


\section{Introduction}

The nature of city dynamics in sub-Saharan Africa is the subject of some dispute. During the past decade it has been commonplace for extremely high rates of urban growth to be predicted with accompanying scenarios of cities growing out of control with ever expanding slums (Nugent and Locatelli 2009, Pieterse 2011). At the same time, claims have been made that certain cities are stagnating and even shrinking (Potts 2009, 2012), though these claims in turn have recently been disputed (Fox, Bloch and Monroy 2017). Ghana has consistently exhibited rapid urbanisation and is one of the few sub-Saharan African countries to have crossed the 50 percent urban threshold. Research has tended to focus on the large cities, however, examining in particular the relative roles of natural increase and migration in accounting for the rate of urbanization and urban growth (Addo 1972, Caldwell 1969, Konadu-Agyemang 2000), the projection of urban population into the future (Owusu and Oteng-Ababio, 2014), and the land-use patterns of urban centres (Bobo 1974, Berkoh 1975, Yankson 2006, Songsore 2009, Owusu 2015, World Bank 2015, Stow et al. 2016).

The extensive unplanned expansion of Ghanaian cities has resulted in sprawl-like, low density, physical developments at the fringes, where land is available more cheaply for housing and other urban uses (Gough and Yankson 2000, 2011). The consequent challenges of such unplanned rapid urban growth has been subject to considerable research, especially the lack of infrastructure and services (Yankson and Gough 1999, Gough and Yankson 2005, Yankson, Kofie and Møller-Jensen 2005, Møller-Jensen and Knudsen 2008, Yankson and Bertrand 2012), and the effects on urban food security (Aduah and Aabeyir 2012, Cobbinah and Amoako 2012, Appiah, Bugri, Forkuo and Boateng 2014, Kuusaana and Eledi 2015). While these aspects of city dynamics occurring broadly at the city or metropolitan scale have been well documented, knowledge of the influence of human mobility and the link between socio-economic transformations of rural areas and their effects on cities is limited, with the available literature for Ghana focussing mainly on Accra and to a lesser extent Kumasi. Even though analysing the dynamics of the major cities is essential in order to understand the factors driving urban growth, this alone does not provide a complete picture. Studying rapidly growing intermediate or secondary cities affords an exploration of the dynamics of such cities which form an important aspect of urban growth (Satterthwaite and Tacoli 2003).

This paper examines the dynamics of physical and social transformation in one of Ghana's secondary cities, Sekondi-Takoradi, focussing on mobility and livelihoods. A modified version of Kaufmann's (2002) 
typology of mobility is built on to examine three key forms of mobility: migration into the city, residential mobility within the city, and the regular mobility of residents. Particular emphasis is placed on illustrating how these different forms of mobility interact with processes taking place both outside and within the city, and the ways in which they inform residents' livelihood strategies. The nature of this interaction is then shown to influence Sekondi-Takoradi's spatial organization and social transformations. This approach provides a counter narrative to much of the empirical research on urban Ghana that typically examines the city and its surrounding rural areas separately. Sekondi-Takoradi is an ideal case study for this reconceptualization, as it has recently risen to prominence due to its recognition as Ghana's 'Oil City', a title based on the agglomeration of services tied to the country's new oil and gas economy being located within its vicinity. Sekondi-Takoradi is also the metropolitan area serving the region's emerging rubber industries, which have had significant effects on the rural economy surrounding the city. In order to examine how, if at all, these processes manifest themselves within the city, qualitative interviews conducted with individuals and groups of residents in five residential neighbourhoods, with diverse socio-economic status located throughout the city, are drawn on. In conclusion, it is argued that the city and its hinterlands can best be envisaged as a mobile networked whole rather than consisting of disconnected and compartmentalised locales.

Following this introduction, the paper briefly presents the conceptual and methodological approach adopted, before providing an outline of the history of Sekondi-Takoradi. The subsequent three sections present empirical findings on the role of mobility in the forms identified above - migration into the city, residential mobility and regular mobility - and explore how they are influencing the spatial and social transformation of Sekondi-Takoradi.

\section{Key concepts and methodology}

The unifying concept across this paper is mobility, a ubiquitous term within the social sciences that has both a spatial and temporal dimension (van Dijk et al. 2001) and exists in a myriad of forms (de Bruijn, van Dijk and Foeken 2001) at a range of scales from the local to the global. Mobility is thus 'engrained in the history, daily life and experiences of people' and is 'inspired by different motives, aspirations and obligations' (de Bruijn et al. 2001, p. 1). Linked to the so-called 'mobility turn' of the last decade in the social sciences, it has been claimed that mobility is so widespread that it should not be seen as a rupture in 
society but as a normal way of life, with immobility being the anomaly (Sheller and Urry 2006). However, while there has been a particular focus in mobility research on advances in new technology, as well as new ways of living and interacting in a global North context, Rigg (2007) has sketched out an alternative new mobilities paradigm which highlights the linkages between mobility and livelihoods in the global South (see also Esson et al. 2016).

In this research we bring together Rigg's (2007) call for mobility to be examined in relation to livelihoods with Kaufmann's (2002) conceptualisation of mobility into four main forms: daily mobility, travel, residential mobility and migration. The four forms are linked to different temporalities: the day and the week for daily mobility, the month and the year for travel, the year and the life course for residential mobility, and the life history for migration (Kaufmann 2002). A key strength of Kaufmann's conceptualisation of mobility is that each form of mobility does not exist in isolation but affects and is affected by the other form, for example, as households move around the city they contribute to the shaping and reshaping of urban areas. In this paper we merge Kaufmann's daily mobility and travel into one category that we call 'regular mobility' resulting in a three-way distinction between migration, residential mobility and regular mobility. Adopting such a process-orientation approach to the mobile city enables an examination of 'the interrelationships of movements of people, objects, capital and ideas in and through the overlapping scales of the local, the body, the national and the global' (Oswin and Yeoh 2010: 170).

Within Sekondi-Takoradi, five residential areas were studied in order to cover a range of settlement types enabling an exploration of how mobility is manifested in differing ways across the city. The residential areas included ones which were: indigenous and non-indigenous dominated, had different histories and social and economic conditions, exhibited differing rates of population growth and wealth status, and were situated in a range of locations within the twin-city. Table 1 provides a brief profile of the settlements selected. 
Table 1: Brief profiles of settlements selected in Sekondi-Takoradi

\begin{tabular}{|l|l|l|l|l|l|}
\hline $\begin{array}{l}\text { Neighbourhood/ } \\
\text { Settlement }\end{array}$ & \multicolumn{1}{|c|}{ History } & \multicolumn{1}{|c|}{ Location } & \multicolumn{1}{|c|}{ Income-level } & $\begin{array}{c}\text { Rate of population } \\
\text { growth }\end{array}$ & $\begin{array}{c}\text { Special } \\
\text { characteristics }\end{array}$ \\
\hline New Takoradi & Indigenous & Central & Low-income & Growing rapidly & Old area \\
\hline Kwesimintsim & $\begin{array}{l}\text { Established } \\
1930 \text { s }\end{array}$ & $\begin{array}{l}\text { Western edge } \\
\text { of centre }\end{array}$ & $\begin{array}{l}\text { Low-income/ } \\
\text { mixed }\end{array}$ & Growing rapidly & Many migrants \\
\hline Anaji & $\begin{array}{l}\text { Indigenous and } \\
\text { newcomers }\end{array}$ & $\begin{array}{l}\text { Northern edge } \\
\text { of centre }\end{array}$ & $\begin{array}{l}\text { Middle/upper } \\
\text { income }\end{array}$ & Growing rapidly & $\begin{array}{l}\text { Includes estate } \\
\text { houses }\end{array}$ \\
\hline Assakae & $\begin{array}{l}\text { Indigenous and } \\
\text { newcomers since } \\
2000\end{array}$ & $\begin{array}{l}\text { Western } \\
\text { periphery }\end{array}$ & $\begin{array}{l}\text { Low/middle } \\
\text { income }\end{array}$ & Growing rapidly & $\begin{array}{l}\text { Farming land } \\
\text { becoming } \\
\text { residential }\end{array}$ \\
\hline Kojokrom & $\begin{array}{l}\text { Indigenous/ } \\
\text { migrants and } \\
\text { newcomers since } \\
2000\end{array}$ & $\begin{array}{l}\text { Eastern } \\
\text { periphery }\end{array}$ & Low-income & $\begin{array}{l}\text { Growing very } \\
\text { rapidly }\end{array}$ & $\begin{array}{l}\text { Commercial } \\
\text { area, railway, } \\
\text { infilling, } \\
\text { densification }\end{array}$ \\
\hline
\end{tabular}

A qualitative approach was adopted as the associated research methods are particularly adept at obtaining data capable of expanding an understanding of the 'sets of meanings which people use to make sense of their world and their behaviour within it' (Cohen, Manion and Morrison 2011: 9), in this case urban residents' mobility and livelihood strategies. Secondary quantitative data - primarily census data - was used to complement the qualitative data collected during the study. Face-to-face interviewing was the primary data collection method used and comprised semi-structured interviews and focus group discussions.

In order to select respondents for the semi-structured interviews, each settlement was divided into four (to ensure that all parts of the settlement were covered) within which respondents of both genders and all ages above 18 engaged in a range of livelihood activities were interviewed. A total of 108 semi-structured interviews were conducted to provide an understanding of the mobility and livelihood strategies of residents of the selected settlements. Whilst a list of potential questions was drawn up in advance, the discussions proceeded in a conversational manner to enable the participants to explore issues they felt were important. The interviews were conducted inside or immediately outside of people's homes or where they were found working within the settlement. They were conducted in the language that the respondent felt most comfortable using, which in many cases was a local language but in some instances was English. Most 
interviews lasted 30-45 minutes, though exceptionally took up to two hours where respondents were keen to talk for longer.

Focus group discussions with four groups - consisting of male youth, female youth, elderly male and elderly female - were also conducted a few days after the individual interviews in all of the settlements (i.e. 20 in total were held). This was to ensure that the views of both genders and a range of ages were heard. Most groups consisted of 6-8 participants and their ages ranged from 18 to mid-30s in the discussions with youth, and from their 40 s upwards in the groups of elders. These groups were put together by a local resource person engaged during the field survey, and the discussions were held in convenient places such as classrooms, a room in the local church or mosque, or in a shady spot in the resource person's compound house. As the focus group discussions were led by the researchers who had conducted the individual interviews, issues which had emerged out of the interviews could be brought into the group discussions. All of the semi-structured and focus group interviews were taped with the consent of participants and subsequently transcribed verbatim. The interview data were then analysed to identify categories and trends, and build themes that link the empirical findings to the wider literature.

\section{Profile of Sekondi-Takoradi}

The twin city of Sekondi-Takoradi, as it is known today, is a coastal metropolitan area located in the southwestern part of Ghana about $280 \mathrm{~km}$ west of Accra. The city originally comprised two separate fishing settlements lying just a few kilometres apart. By the $14^{\text {th }}$ century, these settlements had trading relations with various European powers. In 1644, the Dutch built Fort Orange in Sekondi and subsequently in 1659 they built Fort Witzen in Takoradi, both of which became important trading posts (Obeng-Odoom 2014a). Trade subsequently became central to the development of the twin city of Sekondi-Takoradi supported by the development of ports, harbours and railways (Busia, 1950, cited by Obeng-Odoom 2014a).

Sekondi, the older of the two settlements, had emerged as a town as early as 1894. It experienced rapid growth in its commercial activities, particularly in the precincts near the wharf, due to massive European investment in what eventually became known as the European Quarters. Public sector investments in infrastructure and services resulted in Sekondi receiving the first electricity installation in the country in 1919 (Boahen 2000 cited in Obeng-Odoom 2014a). Takoradi was recognised as a town much later in 1926. 
When a harbour was built shortly after in 1928, Takoradi obtained the country's first artificial port and became an important gateway for overseas trade. The Ghana railway system started from SekondiTakoradi, the first line being built in 1898 from Sekondi to the gold mining town of Tarkwa, subsequently continuing on to Obuasi and later Kumasi. In 1934, the harbour in Takoradi was connected to Sekondi by a double line of track. The harbour and the rail facilities affected the development of Sekondi and Takoradi tremendously, attracting migrants from neighbouring coastal communities and other areas as well as from outside the country, in particular, the countries of the West African sub-region. This migration contributed to the city's cultural and ethnic diversity (Obeng-Odoom 2014a).

In 1946, the two towns were merged into a twin city Sekondi-Takoradi falling under the jurisdiction of one metropolitan council. By 1970, the population of the Sekondi -Takoradi Metropolitan Area (STMA) had reached just over 105,000 , following which it almost trebled to over 300,000 by the year 2000 . A decade later the population had almost doubled in size again reaching nearly 560,000 by 2010 , driven especially by perceived economic opportunities associated with the discovery of oil. Sekondi-Takoradi's rapid population growth, however, has not occurred evenly across all the settlements in the metropolitan area (see Table 2). The core townships of Takoradi and Sekondi, experienced negative population change between 1984 and 2000, and only gained marginally between 2000 and 2010; this loss of population of the two townships to the surrounding municipalities and districts also occurred in the larger cities of Accra and Kumasi (World Bank 2015). Some settlements which experienced very significant population increase between 1984 and 2000 grew more slowly between 2000 and 2010. The highest levels of population change between 2000 and 2010 were experienced in the old fringe settlements, which are relatively low-income and house predominantly migrant communities, such as Kwesimintsim and Kojokrom, as well as in indigenous communities such as Efia village and Ngyeresia. Anaji, an upper middle-income settlement, also experienced high positive population change between 2000 and 2010 . 
Table 2: Sekondi-Takoradi Metropolitan Assembly: Sub-Metros, Settlements, Population and Population Change 1984-2010

\begin{tabular}{|c|c|c|c|c|c|c|}
\hline \multirow[t]{2}{*}{ Sub-metros } & \multirow[t]{2}{*}{ Communities } & \multirow[t]{2}{*}{ Pop 1984} & \multirow[t]{2}{*}{ Pop 2000} & \multirow[t]{2}{*}{ Pop 2010} & \multirow{2}{*}{$\begin{array}{l}\% \text { Change } \\
1984-2000\end{array}$} & \multirow{2}{*}{$\begin{array}{l}\text { \% Change } \\
2000-2010\end{array}$} \\
\hline & & & & & & \\
\hline \multirow[t]{8}{*}{ Kwesimintsim } & Kwesimintsim & 13,852 & 20,024 & 47,211 & 44.6 & $137.77^{\star}$ \\
\hline & Apremdo & 4,772 & 9,437 & 15,402 & 97.75 & 63.20 \\
\hline & W. Tanokrom & 5,140 & 19,217 & 33,990 & 273.87 & 76.87 \\
\hline & E. Tanokrom & 4,388 & 9,296 & 11,689 & 111.85 & 25.74 \\
\hline & Effiakuma & 23,796 & 34,307 & 60,932 & 44.17 & 77.60 \\
\hline & Anaji & 2,460 & 9,274 & 30,397 & 276.99 & $227.76^{*}$ \\
\hline & Assakae & 2,097 & 5,553 & 9,139 & 164.81 & $64.57^{*}$ \\
\hline & Effia-village & - & 4,917 & 10,936 & - & 122.41 \\
\hline \multirow[t]{2}{*}{ Takoradi } & Takoradi & 61,484 & 54,772 & 77,148 & -10.92 & 40.85 \\
\hline & New-Takoradi & - & 13,556 & 20,204 & - & $49.04^{*}$ \\
\hline \multirow[t]{5}{*}{ Sekondi } & Nkontompo & & & 6,586 & & \\
\hline & Kweikuma & & & 13,570 & & \\
\hline & Ekuasi & & & 5,775 & & \\
\hline & Sekondi & 31,916 & 29,247 & 31,011 & -8.36 & 6.03 \\
\hline & Adiembra & 782 & 7,117 & 8,519 & 810.10 & 19.69 \\
\hline \multirow[t]{12}{*}{ Essikado-Ketan } & Fijai & & & 9,729 & & \\
\hline & Butumajebu & & & 5,967 & & \\
\hline & Essikado & - & 11,344 & 20,212 & & 78.17 \\
\hline & Mempeasem & & & 6,314 & & \\
\hline & Ngyiresia & 1455 & 4,752 & 11,861 & & 149.60 \\
\hline & Kojokrom & 876 & 5244 & 37,722 & 498.6 & $783.21^{*}$ \\
\hline & Nkroful & & & 8,206 & & \\
\hline & Kansaworado & & & 8,228 & & \\
\hline & Ntankoful & & & 10,990 & & \\
\hline & Ahenkofikrom & & & 6,264 & & \\
\hline & Mpintsin & & & 6,289 & & \\
\hline & Daebenekrom & & & 6,124 & & \\
\hline
\end{tabular}


Sources: Extracted from 1984 Population Census and 2000 and 2010 Population and Housing Census Reports published by the Ghana Statistical Service

* Settlements/neighbourhoods selected for the study

Sekondi-Takoradi's housing stock has long been inadequate both numerically and in terms of quality. In 1950, only 17 percent of houses in Sekondi-Takoradi had private toilets and even then landlords were converting latrines and kitchens into spaces which they could rent out (Busia 1950 cited in Obeng-Odoom 2014a). Currently, the housing stock in a substantial proportion of the metropolis has been classified as third and fourth class residential areas. Third class residential areas are those with high population density (80-150 persons per acre), high housing density (more than 6 houses per acre), are poorly serviced with regards to utilities often having poor environmental conditions with choked drains, and at times are inaccessible. Fourth class residential areas are less developed indigenous communities which are mostly unplanned areas poorly served with basic social amenities, often lacking drains and with un-engineered roads (STMA, 2011). The challenges of urbanisation seem to have overwhelmed the metropolitan planning and management systems with much development taking place outside of its control.

Sekondi-Takoradi's economy has waxed and waned over the years. The establishment of the seaport and railway provided early booms to the economy. The city became an important industrial centre in the early post-independence era benefiting greatly from the post-independence modernisation policy of the government of the day via import substitution. Most of the industrial establishments, however, collapsed during the 1970s and the early to mid-1980s during prolonged periods of economic crisis. Although some of these were revived during the implementation of economic recovery policy between 1983 and 1987, the overall effects of the structural adjustment programme implemented thereafter led to the collapse of some local industries, compounded by the ill-effects of competition from globalisation (Yankson 2006, 2013).

STMA's economy has bounced back on the manufacturing front in recent years and the port currently handles the export trade of the country's primary commodities of cocoa, timber, bauxite and manganese (World Bank 2015). Since offshore oil and gas deposits were discovered in the Cape Three Points area of the Western Region of Ghana in 2007, Sekondi-Takoradi has acquired another dimension to its economy gaining recognition as an 'Oil city'. Commercial production of oil started in late 2010 while gas production 
only began in 2015. Estimated quantities and exports of oil from the recent Tweneboa, Enyenra and Ntome (TEN) oil fields (with an estimated 23,000 barrels of oil production daily), together with the Jubilee Field and gas from the Atuabo gas plant form the basis of the current optimism Ghanaians have about the future prospects of their national economy (Ablo 2015; Ablo and Overå 2015). Consequently, Sekondi-Takoradi has become the hub for companies involved in the oil industry and associated companies providing services to the oil and gas industry (Obeng-Odoom 2009, 2013, 2014; Yalley and Ofori-Darko 2012).

\section{Migration into Sekondi-Takoradi and residential mobility}

In this section we examine the social composition of migrants, their motives for migrating to SekondiTakoradi, and their initial destination on arriving in the city. We then turn our attention to exploring residential mobility within Sekondi-Takoradi, and consider how this is shaped by external processes. Overall, migrants to STMA are primarily young people of both genders, from a variety of ethnic groups and socio-economic backgrounds and from all corners of Ghana, but especially from within the Western Region. International migrants are also present, particularly from countries in the West African sub region such as Nigeria, Mali, Burkina Faso, Cote D'Ivoire and Togo. The majority of migrants move into STMA primarily for economic reasons, i.e. to explore income-generating opportunities. Some move for social reasons such as marriage, joining family members who have already migrated, and in order to study in the well-respected secondary and tertiary institutions located in STMA. In many ways, this reflects trends seen

in other major Ghanaian cities such as Accra (Gough et al. 2015), Kumasi (Korah, Cobbinah, Nunbogu and Gyogluu 2016) and to a lesser extent Tamale (Fuseini, Yaro and Yiran 2017). In relation to STMA specifically, however, the consistent inflow of migrants is inextricably linked to the emergence of the oil and gas economy. Somewhat surprisingly, cases of economic migrants coming to STMA to capitalise on the region's emerging rubber industries were conspicuous by their absence, with very few participants making reference to the rubber industry or the manufacturing sector as a reason for moving to the city and its environs.

The influx of migrants seeking to earn a living in the 'Oil City' has had a noticeable impact on the cultural and ethnic composition of the city, with even the settlements long recognized as indigenous enclaves now having a cosmopolitan nature, as illustrated by these quotes from interviews conducted in New Takoradi, Kojokrom and Assakae respectively: 
We have the Ahantas, Nzemas, Anlos, Twis, Gas, and Muslims. This town has every tribe in it. The Muslims have even come in their numbers and have come to stay for good (34 year old female fishmonger, New Takoradi).

I can say that the Ahantas are the indigenes and they dominate here and they were the first settlers of this town. But aside that we have other Fantes, Wassas, Ewes, Gas, and northerners as well as several other groups of tribes even including outsiders (46 year old female teacher, Kojokrom).

We have the Ahantas, Anlos, Nzemas, Twis, Gas, and Muslims here. This town has every tribe in it. Ever since the discovery of oil and gas in Sekondi-Takoradi, each and every day you get to see new faces in Assakae. Different people from different places in Ghana, Nigeria and Mali come to this city to look for oil jobs and when they need accommodation they come to Assakae (male Assemblyman, Assakae).

While these quotes show a fairly similar ethnic mix in the different settlements, it is important to note that there is a geography to where incoming migrants decide to settle within Sekondi-Takoradi, with people selecting specific settlements within the city for various reasons. For example, Kojokrom, which is located on the eastern periphery of the city, still draws incoming migrants to the area because of its cheap accommodation rates in comparison to more central locations, despite the railway terminal being almost defunct. A similar story is unfolding in Assakae and the historically indigenous settlements. Meanwhile, New Takoradi has become an attractive area particularly for younger migrants due to the availability of affordable accommodation and the relative ease of transportation to other parts of the city, including the CBD where people perceive there are job opportunities especially in the informal economy. Likewise, Kwesimintsim has historically attracted people from across Ghana and internationally because of the availability of land for building, the affordable rental accommodation and transport connections with the CBD, the port and industrial areas of Takoradi. Today, Kwesimintsim attracts migrants seeking opportunities in the 'new' economy and its related sub-sectors who are seeking rental accommodation primarily because opportunities to purchase land to build a property are diminishing. Aisha, a 55-year-old female lotto vendor succinctly explained the situation as follows, 'If you need a land here [in Kwesimintsim] you will not get because all the lands here are finished'. 
Given the pressure for residential space within Sekondi-Takoradi, there is an increasing trend for residents to move between areas, especially from the core areas such as New Takoradi and Kwesimintsim, to the peripheral areas such as Assakae. The catalyst for this residential mobility is excess demand over supply of housing, which has made it difficult for many migrant households to find affordable housing. Consequently, as a coping strategy, some migrants collectively erect makeshift metal containers or wooden stores that can be used for their work during the day and as a sleeping place at night. These structures can be seen as a form of creative and practical collaboration among residents who are seemingly marginalized from and struggling to get to grips with urban life, a type of conduct comparable to the notion of 'people as infrastructure' (Simone 2004). There is some disquiet, however, that these buildings are hindering the city's ability to attain a modern aesthetic befitting its status as an oil city, and generating health and environmental risks as the vast majority of these structures are poorly built and lack appropriate access to water and sanitation services.

Obeng-Odoom (2013) notes that excess demand over supply of housing within Sekondi-Takoradi is linked to the pervasive desire to attain profit through residential property markets, which is indicative of the oilurbanisation-urbanism nexus. This situation is evidenced by the practices of landlords in central areas who are converting facilities such as kitchens, washrooms and store rooms into sleeping spaces in order to extract maximum profit from migrants seeking rental accommodation in the 'oil city'. Moreover property owners are converting residential units in central locations like Takoradi market circle area into commercial spaces and offices with a view to attracting those affiliated with the emerging oil and gas market. In Kwesimintsim it is common to find a building housing companies and offices in the ground and 1st floors while the top floors are being used as residence for the immediate family of the landlord. The desire to leverage rental income is resulting in rising rents which is driving existing migrant tenants out of central areas to find cheaper and higher standard accommodation elsewhere in the city. Some indigenes of New Takoradi are moving out of their centrally located family homes in order to rent them out, using the profits to build new homes in the fringe areas.

This desire to leverage rental income is not only restricted to the central areas but is also evident in the fringe zones of Takoradi, particularly Assakae's densely populated indigenous core where landlords are converting and leasing rooms vacated by family members to cater for the growing demand for affordable housing in STMA. A noticeable outcome of this desire to maximise rental income is that infilling of spaces between properties and makeshift building extensions are now pervasive; although participants stressed 
that this infilling was a means to address housing demand and earn an income, they acknowledged that it also came at a cost to the wider community in the form of poor ventilation, uneasy access routes, blocking of waterways, and inhibiting construction of roads and drains by the municipal authorities. This situation also places additional pressure on already overstretched infrastructural services such as water, electricity, waste management and sanitation facilities.

In contrast to the more densely populated indigenous core, which has become a hotspot of tenants, the land just beyond this, which was formerly agricultural land, has become an attractive destination for residents and companies seeking sizeable yet affordable plots of land for development. This area thus contains a mix of single and multi-storey buildings of architecturally diverse designs which are at different stages of completion. The majority of these houses are self-contained (detached), with single family ownership and occupancy, and are currently characterised by low population density. Kojokrom in particular has experienced rapid urbanisation of its farmlands in recent years; previously acquired plots of land in Kojokrom and large parcels of farmland in the surrounding area are continuously being acquired by individuals and multi-national companies for commercial development.

Social and physical transformations are also taking place in the middle- and upper-income residential areas, as the situation in Anaji shows. Wealthier individuals and non-indigene families who have lived in other parts of Sekondi-Takoradi, and indigenes from densely populated areas of the city, are moving to Anaji because of its reputation as a peaceful and secure area with a good layout and clean environment. This reputation is tied to the area's historical association with civil and public servants. Additionally, the emerging oil and gas industry is altering Anaji's local economy as companies related to the industry are opening branch offices there. Consequently, oil executives and middle-class workers in the related service sectors have relocated to buy and rent properties in Anaji. This has increased economic rents and property values, and encouraged the conversion of residential spaces into administrative and commercial units, which have also attracted other services such as banking and micro-financial institutions. Like in Accra (Oosterban et al. 2012), the conversion of residential properties to commercial spaces in Anaji and areas with similar characteristics is caused by a disparity between demand and supply for retail and office space, infrastructural development and redevelopment.

A key implication of the conversion of domestic properties to commercial spaces located in prosperous residential areas, is a further reduction in available housing stock. One high profile response to this situation, and a key example of the interrelated nature of urban dynamics within Sekondi-Takoradi, is the 
'King City' new town development project led by the Renaissance Group. The King City project is located on rural land north of Assakae, a position that enables it to act as a dormitory town to absorb the growth of Takoradi and its environs away from the populated city centre. The Renaissance Group has procured 2,400 acres of land (a 1,018-hectare site), which will be leased to real estate developers as well as individuals. Over the next 10-15 years, the King City development aims to create 24,000 dwelling units catering for 98,000 residents through a mix of low-, medium- and high-density residential areas, large retail and shopping centres, and light industrial and commercial buildings, as well as leisure facilities (www.kingcity.com.gh/).

It is perhaps telling that while publically available information on the 'King City' development claims it will benefit Assakae and its surroundings, and also help to ease the burdens of urbanization in STMA (www.kingcity.com.gh/), the vast majority of participants, including residents of Assakae, were unaware of the 'King City' development and could not envision themselves ever going there when it was described to them. What is clear is that large-scale developments on the outskirts of the city are associated with dubious and contested financial arrangements between traditional chiefs, who are often the custodians of sizeable land parcels, and property developers (see also Obeng-Odoom 2013). As the Assemblyman of Assakae lamented:

In the past the land was used for farming but nowadays there are a lot of buildings here. After the oil and gas discovery and exploration, people are buying large acres of land at cheaper prices from the chiefs under the pretext of using them for development projects. But you will realize after a long time that they resell these lands to the oil companies and other business people, who later contract it to the estate developers for commercial purposes.

This highlights how complex land negotiations, linked to expected mobility in relation to the emerging oil and gas industry, are transforming the spatial and social layout of the city.

\section{Livelihoods and regular mobility in Sekondi-Takoradi}

Despite being considered an 'oil city', data from the 2010 Ghana Population and Housing Census (GSS 2012) show that STMA is not very different from the other metropolitan areas in the country in terms of livelihood activities. Almost half (49 percent) of the population aged 15 years and above are self-employed, 
30 percent are service and trade workers, and 20 percent are engaged in craft and related activities. The private sector is the dominant sector employing 78 percent of the labour force, though the majority of these (64 percent of the labour force) are in the private informal sector with only 14 percent employed by the private formal sector. The key sectors in terms of employment in Sekondi-Takoradi are wholesale and retail (27.1 percent), manufacturing (17.4 percent), and agriculture/forestry/fishing (9.1 percent) (see Table 3).

Table 3: Employment by sectors in Sekondi-Takoradi in 2010

\begin{tabular}{|lc|}
\hline Sectors & Percentage employed \\
\hline Agric/Forestry/Fishing & 9.1 \\
Mining & 1.0 \\
Manufacturing & 17.4 \\
Construction & 5.1 \\
Transport & 7.4 \\
Accommodation, food service & 8.6 \\
Wholesale and retail & 27.1 \\
Finance and insurance & 1.4 \\
Public administration, defence, & 3.9 \\
compulsory service & \\
Education & 5.7 \\
Human health, social work & 1.6 \\
All other sectors & 11.7 \\
Sample size & 256,583 \\
\hline
\end{tabular}

Source: Compiled from Data provided by Ghana Statistical Service (GSS): Ghana 2010 Population and Housing Census (unpublished)

Trading is the key employment sector in Sekondi-Takoradi dominated by a large informal economy; although traders are scattered throughout the city, including in residential areas, they are concentrated along the main roads and in markets, the largest of which are Market Circle in Takoradi, Sekondi Market and Apremdo Market (STMA 2011). The traders range from: street vendors (referred to as hawkers in Ghana) who carry their goods in their hands or on their heads; vendors with minor facilities such as a table; 
traders operating out of makeshift structures/sheds; traders with lockable containers or other types of prefabricated structures; and, at the top of the hierarchy, traders running their businesses out of purposebuilt retail buildings (see also Afutu-Kotey 2016). Manufacturing at all scales of operation is another key employment sector of the twin city. Most of the large-scale manufacturing units are not functioning or are producing under capacity but there are some vibrant light industrial activity areas including the Kokompe No. 1 and No. 2 areas in Takoradi, which host mechanics and local artisans.

Fishing and farming, which together form the third most important sector for employment, have been the traditional livelihood activities in Sekondi and Takoradi from the early years of their development. The fishing industry constitutes a complex food chain, made up of fishermen, fish traders or fishmongers (who are often women), retailers and other actors at the base of the chain who supply inputs to the fishing industry (Obeng-Odoom 2014b). Much of the medium- and large-scale fishing activities occur in and around the Albert Bosomtwe-Sam Fishing Harbour in Sekondi, which has an associated commercial area consisting of banking institutions, offices, private cold stores of 80-6000 tons capacity, a fish processing plant, fish market, food market and restaurants (STMA 2011).

In the settlements located along the coast of STMA, such as New Takoradi, Sekondi and Ngyiresia, where fishing has long been the main livelihood activity, residents engage in small-scale fishing. In the past, the men of the community went to sea to catch the fish, while their female counterparts engaged in fish smoking, the buying and selling of fish (including frozen fish) and trading in fish related commodities. Existing research has yet to verify the impact of oil exploration on Sekondi-Takoradi's fishing industry (Obeng-Odoom 2014b), however, participants residing in New Takoradi argued that following the discovery and exploration of oil and gas in commercial quantities in the Tano Basin, the fishing industry has become highly precarious and economically unviable (see Dowokpor 2015). As one resident of New Takoradi claimed:

The men go to the sea to fish because that is the work we do here basically. But these days when they go they end up coming with sea crabs and smaller fishes which do not give the women any profit when we smoke and sell them. This is because of the oil drills which have polluted our sea of late (48 year old female fishmonger, New Takoradi).

The difficulties facing the local fishing industry were attributed by our informants to two key issues. First, the release of chemicals and oil into the sea, as part of the development and production phase, are thought to 
be killing fish stock and thereby reducing the amount of fish caught. Second, fish are now inclined to gravitate towards the offshore oil rigs because they are attracted to the light being emitted by the infrastructure. This is problematic because fishermen are prohibited from entering the waters near the oil rigs for safety and security reasons. A key outcome of these circumstances has been the near collapse of the fishing industry, which renders other ancillary workers and service providers, such as boat-making craftsmen, cooked food vendors, and oil suppliers out of business. This is a further reason why residents in areas like New Takoradi are investing in property as an alternative income source.

Farming is the other major primary activity undergoing change within STMA. Rapid peri-urban development and the expansion of land acquisition to service the oil and gas industry, as well as for new housing development in the fringe areas, especially in Assakae, have resulted in the loss of land to farming communities in the fringe areas of Sekondi-Takoradi. In Assakae, farming is only an occupation for a relatively small number of residents, mostly elderly men and women who cultivate food crops including cassava, plantain, tomatoes, pepper, sugar cane as well as some cash crops, such as oil palm and cocoa. The foodstuff from the farms is often sold in the Thursday market in Assakae which, though not as economically active as before, serves as an attraction and trading opportunity for residents of the surrounding villages (including Whindo, Adientiem, and Mpatado) and the city centre. While the local people bring foodstuff and fish, residents from the city centre bring household and manufactured items to sell. The extent of farming is continuing to decline as large parcels of land are being purchased by the oil companies and estate developers and converted into residential and commercial buildings, which results in the available land being located further afield. Due to poor transport and the high cost of taxis, it has become difficult to make the journey on a daily basis, whilst the old age of most of the farmers means they find the journey tiring.

With growing apathy among the youth towards farming (Sumberg et al. 2012, Gough and Birch-Thomsen 2016), which has greatly declined its future prospects, most young people work within the informal economy (Gough, Langevang and Owusu 2013). Young men typically work as masons, electricians and plumbers etc. at construction sites, or in service jobs, such as barbers, drivers and conductors, washing bay operators, and as petty traders. Some of the male indigene youth engage in survivalist strategies, such as sand and stone winning, and palm wine tapping. Meanwhile the young women are primarily small-scale provision shop owners and petty traders who primarily sell perishable goods including food they have cooked themselves, sometimes hawking with their merchandise from home to home. Others work as 
seamstresses, hairdressers, sell mobile phone credit or run chop bars (small restaurants) (see also Langevang and Gough 2012, Langevang, Gough, Yankson, Owusu and Osei 2015).

The backbone of income-generating activities is the urban transportation network (Esson et al. 2016). Residents criss-cross the entire physical and economic space of Sekondi-Takoradi using various means of transport including: walking, use of private cars, and all forms of public transport including taxis and trotros (privately owned minibuses). Trotros provide good connectivity to other economic hubs in the city, with commuters moving out of the settlement daily to work, including traders travelling to the Takoradi Central Market (as early as $5 \mathrm{am}$ ) to buy foodstuff and goods for their households and home-based enterprises. The inadequate number of vehicles, however, leads to long queues during the peak morning and evening periods, and the road infrastructure is in a deplorable condition with the majority of the minor roads untarred with deep potholes. As a young man resident in Kojokrom complained:

Some of the drivers don't want to come here and spoil their cars, so most of the vehicles used here are very old. Even for some of the trotros when you are inside you can see the road from the floor of the car and when it rains and they hit a 'manhole' it splashes water on you. This is our number one worry since most people go to town to work and those who remain here sell by the roadsides and they complain about the dust (20 year old male, mechanic, Kojokrom).

The bad state of transport services thus negatively affects mobility and income-generating activities within Sekondi-Takoradi. In addition to creating challenges for commercial activities, some of the respondents also mentioned that the lack of a direct access route by cars from the surrounding farming areas increases travel time and cost, thus reducing the quantity of foodstuff brought by the farmers.

\section{Conclusions}

Existing research on urban change in sub-Saharan Africa, including Ghana, has tended to focus on larger cities at the expense of secondary and intermediate cities, while also overlooking the link between socioeconomic transformations of rural areas and their effects on cities. Accordingly, this paper sought to qualify these trends and further existing research by examining how the spatial and social transformation of Sekondi-Takoradi, one of Ghana's key secondary cities, is being shaped by different forms of mobility, both into and within the city. The inflow of migrants into the twin city has been boosted by the region's newly 
acquired role as the centre of the oil and gas industry in Ghana. Yet somewhat surprisingly, cases of economic migrants coming to STMA to capitalise on the region's emerging rubber industries were conspicuous by their absence, with very few participants making reference to the rubber industry or the manufacturing sector as a reason for moving to the city and its environs. Migrants searching for new opportunities have moved to the city from throughout Ghana, not just from neighbouring rural areas. In fact, changes in the rural areas surrounding Sekondi-Takoradi were found to have had little impact on demographic transformations in the city.

Extensive residential mobility within the city has left its imprint on the physical face of STMA through increased demand for rentable accommodation, especially in both the indigenous and migrant dominated low-income settlements. Opportunistic landlords have, therefore, converted service rooms into living spaces and extended buildings to create more space to maximise rental income. While this may make for a lucrative business model, it also results in overcrowded living environments that typically lack basic amenities and services. Relatedly, due to the excess demand for housing over supply, migrants desperate for accommodation are erecting temporary structures in-between buildings and in alleyways. The overall effect has been further densification of already crowded neighbourhoods and increased pressure on services and infrastructure. Added to this, the establishment of commercial activities, banks and offices in former residential spaces, while enhancing the opportunities they offer landlords for converting their properties from residential to commercial use for higher rental value, has had a negative impact on the housing supply.

The paper has also highlighted how peripheral or fringe areas of Sekondi-Takoradi are growing rapidly through uncontrolled urbanisation of farm lands, despite these areas having limited service provision and infrastructure more generally. Most of those moving into the periphery of the city are escaping the increasingly overcrowded inner areas, though some newcomers to the city are also moving directly into these newly developing areas. Regardless of their location, residents need to move around the city, some on a frequent basis and often in relation to their livelihood activities, but all have to deal with an inadequate transport infrastructure. The urban planning and management system of STMA has to respond adequately to these challenges if the city is to play its role as the emerging 'oil city' of Ghana. Overall, the paper has revealed how the city can best be envisaged as a mobile networked whole rather than consisting of disconnected and compartmentalised locales (Skelton and Gough 2013). This has implications beyond this study for how we should conceptualise, study and manage secondary cities. 


\section{References}

Ablo, A. D. (2015). Local content and participation in Ghana's oil and gas industry: Can enterprise development make a difference? The Extractive Industries and Society, 2, 320-327

Ablo, A. D. and Overå, R. (2015). Networks, trust and capital mobilisation: challenges of embedded local entrepreneurial strategies in Ghana's oil and gas industry. Journal of Modern African Studies, 53(3), 391-413.

Addo, N. (1972). Urbanization, population and employment in Ghana. In S. Ominde and C. Ejiogu, Eds. Population Growth and Economic Development in Africa. Heinerman, pp. 243-251.

Aduah, M.S. and Aabeyir, R. (2012). Land cover dynamics in Wa Municipality, Upper West Region of Ghana, Research Journal of Environmental and Earth Sciences 4(6), 658-664,

Afutu-Kotey, R.L. (2016). Young entrepreneurs in the mobile telephony sector in Ghana, in Gough, K.V. and Langevang, T. (eds) 2016 Young entrepreneurs in sub-Saharan Africa, London and New York, Routledge

Appiah, D.O., Bugri, J.T., Forkuo, E.K. and Boateng, P.K. (2014). Determinants of Peri-Urbanization and Land Use Change Patterns in Peri-Urban Ghana, Journal of Sustainable Development, 7(6), 95108

Berkoh, D., (1975). Perception, migration and urban primacy in Ghana: a study of Accra-Tema metropolitan area. Bulletin of the Ghana Geographical Association, (17), 80-95.

Boahen, A. (2000). Ghana: Evolution and change in the nineteenth and twentieth centuries, Sankofa Educational Publishers Ltd., Accra

Bobo, B. (1974). Economic factors influencing migration, urban growth and structure, Accra, Ghana. Doctoral Thesis. University of California, Los Angeles.

Busia, K.A. (1950). A Report on a social survey of Sekondi-Takoradi, Crown Agents for the Colonies for the Government of the Gold Coast, London

Caldwell, J. (1969). African rural-urban migration. The movement to Ghana's towns., Australian National University Press. 
Cobbinah, P.B. and Amoako, C. (2012). Urban Sprawl and the Loss of Peri-Urban Land in Kumasi, Ghana International Journal of Social and Human Sciences, 6, 388-397

Cohen, L., Manion, L., and Morrison, K. (2011). Research Methods in Education. Routledge, London

De Bruijn, M., Van Dijk, R., and Foeken, D. (2001). Mobile Africa: an introduction. In M. De Bruijn, R. A. van

Dijk, \& D. Foeken, (Eds.). (2001) Mobile Africa: changing patterns of movement in Africa and beyond. Brill, Leiden: 1-7.

Dowokpor, V. (2015). Impacts of the oil and gas industry on the livelihoods of men and women working in the fisheries: a study of Shama, Ghana. Master's thesis. University of Bergen, Norway.

Esson, J., Gough, K.V., Simon, D., Amankwaa, E.F., Ninot, O. and Yankson, P.W.K. (2016). Livelihoods in motion: Linking transport, mobility and income-generating activities, Journal of Transport Geography, 55, 181-188

Fox, S., Bloch, R. and Munro, J. 2017 Understanding the dynamics of Nigeria's urban transition: a refutation of the stalled urbanization hypothesis, Urban Studies (forthcoming)

Fuseini, I., Yaro, J. A., and Yiran, G. A. (2017). City profile: Tamale, Ghana. Cities, 60, 64-74.

Ghana Statistical Service (GSS) (2012) 2010 Population and Housing Census: Summary Report of Final Results, Accra, Ghana Statistical Service, May

Gough, K.V.; Andreasen, M.H.; Esson, J.; Mainet, H.; Namangaya, A.H.; Yankson, P.; Agergaard, J.; Amankwaa, E.F.; Kiunsi, R.; Møller_Jensen, L. and Yemmafouo, A. (2015). City dynamics: mobility and livelihoods of urban residents, RurbanAfrica Work Package 3, Report No. 2, 2015, RurbanAfrica, Department of Geosciences and Natural Resource Management, University of Copenhagen

Gough, K.V. and Birch-Thomsen, T. (2016). Mobile rural youth in northern Ghana: combining near and distant opportunity spaces, in Gough, K.V. and Langevang, T. (eds) Young entrepreneurs in subSaharan Africa, London and New York, Routledge

Gough, K.V., Langevang T., Owusu, G. (2013). Youth employment in a globalising world, International Development Planning Review, 35(2): 91-102 
Gough, K.V. and Yankson, P.W.K. (2000). Land markets in African cities: the case of peri-urban Accra, Ghana. Urban Studies, 37(13), pp. 2485-2500.

Gough, K.V. and Yankson, P.W.K. (2005). Conflict and Co-operation in Environmental Management in Peri-Urban Accra in The Peri-Urban Interface: Approaches to Sustainable Natural and Human Resources Use: Mcgregor D, Simon, D. and Thompson, D (eds) London, Earthscan p196-210 ISBN 13: 978-1-84407-188-3

Gough, K.V. and Yankson, P.W.K. (2011). A Neglected Aspect of the Housing Market: The Caretakers of Peri-Urban Accra, Ghana, Urban Studies 48(4): 793-810

Grieco, M., Apt, N.A. and Turner, J. (1996). At Christmas and on rainy days: transport, travel and the female traders of Accra, Avebury.

Kaufmann, V. (2002). Re-thinking Mobility. Contemporary Sociology, Ashgate, Aldershot

Konadu-Agyemang, K. (2000). The best of times and the worst of times: Structural adjustment programs and uneven development in Africa: the case of Ghana. The Professional Geographer, 52(3), pp.469-483.

Korah, P. I., Cobbinah, P. B., Nunbogu, A. M., and Gyogluu, S. (2016). Spatial plans and urban development trajectory in Kumasi, Ghana. GeoJournal, 1-22.

Kuusaana, E.D. and Eledi, J. A. (2015). As the city grows, where do the farmers go? Understanding Periurbanization and food systems in Ghana - Evidence from the Tamale Metropolis, Urban Forum DOI 10.1007/s12132-015-9260-x

Langevang, T. and Gough, K.V. (2012). Diverging pathways: young female employment and entrepreneurship in sub-Saharan Africa, The Geographical Journal, 178(3), p.242-252.

Langevang, T., Gough, K.V., Yankson, P., Owusu, G. and Osei, G. (2015). Bounded entrepreneurial vitality: the mixed embeddedness of female entrepreneurship, Economic Geography, 9(4), p.449473

Møller-Jensen, L. and Knudsen, M.H. (2008). Patterns of population change in Ghana (1984-2000): urbanization and frontier development. GeoJournal, 73(4), pp.307-320. 
Nugent, P. and Locatelli, F. (eds) (2009). African cities: competing claims on urban spaces, Leiden: Brill

Obeng-Odoom, F. (2009). Oil and Urban Development in Ghana, African Review of Economics and Finance, 1(1), 18-39.

Obeng-Odoom, F. (2013). Resource curse or blessing in Africa's oil cities? Empirical evidence from Sekondi-Takoradi, West Africa. City, Culture and Society, 4(4), 229-240.

Obeng-Odoom, F. (2014a). Oiling the urban economy: Land, labour, capital and the state in SekondiTakoradi, Ghana, London, Routledge

Obeng-Odoom, F. (2014b). Black gold in Ghana: crude days for fishers and farmers?. Local Environment, 19(3), 259-282.

Oswin, N., and Yeoh, B. S. (2010) Introduction: mobile city Singapore. Mobilities, 5(2): 167-175.

Owusu, G. (2015). Decentralized development planning and fragmentation of metropolitan regions: The case of the Greater Accra Metropolitan Area, Ghana, Ghana Journal of Geography 7(1), 1 - 24.

Owusu G., and Oteng-Ababio, M. (2014) Moving unruly contemporary urbanism toward sustainable urban development in Ghana by 2030, American Behavioral Scientist 1-17

Pieterse, E. (2011). Grasping the unknowable: coming to grips with African urbanisms. Social Dynamics, $37(1), 5-23$.

Potts, D. (2009). The slowing of sub-Saharan Africa's urbanization: evidence and implications for urban livelihoods. Environment and Urbanization, 21(1), 253-259.

Potts, D. (2012). "What do we know about urbanisation in sub-Saharan Africa and does it matter?" International Development Planning Review 34(1), V-XXI.

Rigg, J. (2007) An everyday geography of the global south. Routledge, New York. 
Satterthwaite, D., and Tacoli, C. (2003). The urban part of rural development: the role of small and intermediate urban centres in rural and regional development and poverty reduction. IIED Working Paper Series on Rural-Urban Interactions and Livelihood Strategies: Working Paper 9. Available at: http://pubs.iied.org/9226IIED/

Sekondi Takoradi Metropolitan Assembly (STMA) (2011). Preparation of Sekondi-Takoradi Spatial Plan: Progress Report 1, October 2011

Simone, A. (2004). People as infrastructure: intersecting fragments in Johannesburg. Public culture, 16(3), 407-429.

Sheller, M., and Urry, J. (Eds) (2006). Mobile technologies of the city. Routledge, New York.

Skelton, T. and Gough, K.V. (2013). Young people's im/mobile urban geographies: introduction, Urban Studies, 50(3), 455-466.

Songsore, J. (2009). The Urban Transition in Ghana: Urbanization, National Development and Poverty Reduction. Available at: http://pubs.iied.org/pdfs/G02540.pdf.

Stow, D.A, Weeks, J. R., Hsiao-chien, S., Lloyd, L. Coulter, H. J., Yu-Hsin T., Kerr, A., Benza, M., Mensah, F. (2016): Inter-regional pattern of urbanization in southern Ghana in the first decade of the new millennium, Applied Geography 71, 32-43

Sumberg, J., Anyidoho, N. A., Leavy, J., te Lintelo, D. J. H., and Wellard, K. (2012). Introduction: The young people and agriculture "problem" in Africa. IDS Bulletin, 43(6), 1-8.

Yalley, P. P and Ofori-Darko, J. (2012). The Effects of Ghana's Oil Discovery on Land and House Prices on communities nearest to the oil filed in Ghana (Case Study: Kumasi and Sekondi-Takoradi) In: Laryea, S., Agyepong, S., Leiringer, R. and Hughes, W. (Eds) Procs 4th West Africa Built Environment Research (WABER) Conference, 24-26 July 2012, Abuja, Nigeria, 1443-1454.

Yankson, P.W.K. (2006). Urbanization, industrialization, and national development: challenges and prospects of economic reform and globalization, Ghana Universities Press. 
Yankson, P.W.K. (2013). Aspects of Manufacturing Geography in Ghana. In Owusu, G. S. Adjei-Mensah, P.W.K. Yankson and E.M. Attua (Eds): Readings in Geography. Essays in Commemoration of the $65^{\text {th }}$. Anniversary of University of Ghana (Social Science Series 1. Woeli Publishing Service, Accra; ISBN 978-9988-626-10-X pp 116-133

Yankson, P. and Bertrand, M. (2012). Challenges of urbanization in Ghana. In E Ardayfio-Schandorf, P. Yankson, and M. Bertrand, eds. The Mobile City of Accra: Urban Families, Housing and Residential Practices. CODESRIA, p. 288.

Yankson, P.W.K. and Gough, K.V. (1999). The environmental impact of rapid urbanization in the peri-urban area of Accra, Ghana, Danish Journal of Geography, 99, 89-100.

Yankson, P., Kofie, R.Y. and Møller-Jensen, L. (2005). Monitoring urban growth: Urbanization of the fringe areas of Accra. Bulletin of the Ghana Geographical Association, 24 1-13

World Bank (2015). Rising through cities in Ghana: Ghana urbanization review overview report.

Washington, DC. 